\title{
DEFORMATION BEHAVIOUR OF AMORPHOUS Fe-Ni-W/Ni BILAYER-CONFINED BULK METALLIC GLASSES
}

\author{
OBNAŠANJE DEFORMIRANEGA, AMORFNEGA, NA DVE PLASTI \\ OMEJENEGA KOVINSKEGA STEKLA Fe-Ni-W/Ni
}

\author{
Ho Kuen Lau, Natalie Yip, Shun Hua Chen, Wen Chen, Kang Cheung Chan \\ Advanced Manufacturing Technology Research Centre, Department of Industrial and Systems Engineering, \\ Hong Kong Polytechnic University, Hong Kong \\ kc.chan@polyu.edu.hk
}

Prejem rokopisa - received: 2014-09-02; sprejem za objavo - accepted for publication: 2015-03-24

doi:10.17222/mit.2014.217

\begin{abstract}
In this study, an amorphous Fe-Ni-W/Ni bilayer was successfully electroplated on a Zr-based bulk metallic glass (BMG), and the deformation behaviour of the bilayer-coating-confined BMG was investigated. The findings show that the macroscopic plasticity of the BMGs was enhanced from $1.3 \%$ to $10.7 \%$. More importantly, bilayer-confined BMGs have a large plateau of the serrated flow with an insignificant decrement before failure. When characterizing the serrated flows of both uncoated and bilayer-confined BMGs by introducing absolute values of stress raises/drops, smaller amplitudes of stress drops as well as a larger stress-drop frequency during the plastic-deformation stage were found in the bilayer-confined BMGs. The origin of the increased stable plastic flow was discussed, and it is mainly attributed to the enhanced confinement caused by the introduction of the amorphous layer. The findings are significant for enhancing the macroscopic plasticity of the BMGs and for understanding the deformation mechanism of the serrated plastic flow in geometrically confined BMGs.
\end{abstract}

Keywords: plastic flow, bulk metallic glass, amorphous Fe-Ni-W coating, geometric confinement

V študiji je bilo uspešno elektroplatirano amorfno, dvoplastno steklo Fe-Ni-W/Ni, na masivno kovinsko steklo (BMG) na osnovi Zr. Hkrati je bilo preiskovano obnašanje dvoplastnega BMG pri deformaciji. Ugotovitve kažejo, da se je makroskopska plastičnost BMG povečala z $1,3 \%$ na $10,7 \%$. Se bolj pomembno je, da ima dvoplasten BMG visok plato nazobljenega dela krivulje z nepomembnim zmanjšanjem pred porušitvijo. Pri karakterizaciji nazobčanega poteka pri obeh; nepokritem in pri dvoplastnem BMG, z vpeljavo absolutne vrednosti narastka in padca napetosti, so bile dobljene manjše amplitude padca napetosti kot tudi večja pogostost padca napetosti med plastično deformacijo dvoplastno omejenega BMG. Razložen je izvor povečanja stabilnega plastičnega toka, ki se ga pripisuje okrepitvi, ki jo povzroči amorfna plast. Ugotovitve so pomembne za povečanje makroskopske plastičnosti BMG in za razumevanje deformacijskega mehanizma nazobčanega plastičnega toka $v$ geometrijsko omejenem BMG.

Ključne besede: plastični tok, masivno kovinsko steklo, amorfna Fe-Ni-W plast, geometrijska omejenost

\section{INTRODUCTION}

In recent years, due to the extraordinary mechanical properties of bulk metallic glasses (BMGs), such as the high strength and high elastic strain, there has been a growing interest in exploring the application potential of BMGs as structural materials. ${ }^{1-6}$ It is known that plastic deformation occurs mainly in thin shear bands, and a sharp drop in viscosity in deformation zones facilitates a propagation of the existing shear bands, resulting in the final catastrophic failure of BMGs. ${ }^{1,7}$ Macroscopically, the initiation and propagation of shear bands are manifested in serrated plastic flows in the stress-strain curves. ${ }^{8-11}$ The serrated flow can be characterised as repeating cycles of elastic loading and unloading where the loading can be classified as elastic deformation and the unloading is caused by an inelastic displacement from a localized shear-band propagation..$^{8-12}$ In order to increase the plasticity of a material, the nucleation of the shear bands must be encouraged and the propagation inhibited to avoid catastrophic failure of the shear bands, i.e., a sudden drop in the load in the flow serrations. ${ }^{13}$
Over the years, geometric confinement has been proven effective in improving the plasticity of BMGs. ${ }^{14-18}$ For example, by electroplating a single coating layer of $\mathrm{Ni}$, the plasticity of a nominally "brittle" Fe-based BMG was increased from $0.5 \%$ to $5 \% .{ }^{16}$ In 2012, Chen et al. ${ }^{17}$ reported an improvement in the plasticity of a Zr-based BMG using a $\mathrm{Cu} / \mathrm{Ni}$ bilayer coating, in which the soft $\mathrm{Cu}$ coating absorbs the loading stress while the hard Ni layer imposes a confining effect. The bilayer coating successfully increased the plasticity of the as-cast $\mathrm{Zr}$-based BMG from $1.3 \%$ to $11.2 \% .{ }^{17}$ The disadvantage, however, turns out to be a significant drop in the plastic-flow stress upon reaching a $7 \%$ macroscopic plasticity. Similar phenomena can also be found in single $\mathrm{Ni}$ or $\mathrm{Cu}$ layer confined BMGs. ${ }^{17}$

In a recent work, by applying a MG/Ti bilayer on a Zr-based BMG, Chu et al. ${ }^{19}$ managed to significantly increase its bending plasticity, as compared with the uncoated BMG, the BMGs coated with a single layer of MG or a single layer of Ti. It was shown that the bilayer is capable of absorbing the deformation by initiating a large number of tiny shear bands, which may provide a 
possible way to further suppress the propagation of the shear bands in BMGs in order to achieve a more stable plastic flow. ${ }^{19}$ In the present study, an amorphous Fe-Ni-W/Ni bilayer was successfully electroplated on a Zr-based BMG and a more stable plastic flow was achieved.

\section{EXPERIMENTAL WORK}

As-cast $\mathrm{Zr}_{57} \mathrm{Cu}_{20} \mathrm{Al}_{10} \mathrm{Ni}_{8} \mathrm{Ti}_{5}$ (amount fractions, $x / \%$ ) BMG specimens of a 2-mm diameter were prepared by sucking an arc-melted mixture of high-purity raw materials into a copper mould. The electronic plating of an amorphous $\mathrm{Fe}-\mathrm{Ni}-\mathrm{W}$ coating on the BMGs was first carried out using an electrolyte with the composition shown in Table 1, which is a modification of the one from $^{20}$. The $\mathrm{pH}$ value of the electrolyte was kept at 8 , with the current set at $50 \mathrm{~mA}$ for $24 \mathrm{~h}$. The amorphous nature of the as-cast BMG specimens and the Fe-Ni-W coating was confirmed using an X-ray diffractometer (XRD), and the composition of the amorphous Fe-Ni-W coating was examined using an energy-dispersive X-ray spectrometer (EDS).

Table 1: Electrolyte composition for the amorphous Fe-Ni-W layer deposition

Tabela 1: Sestava elektrolita pri nanašanju plasti amorfnega $\mathrm{Fe}-\mathrm{Ni}-\mathrm{W}$

\begin{tabular}{|c|c|}
\hline Component & Concentration $/ \mathrm{mol} \mathrm{L}^{-3}$ \\
\hline Iron sulphate & 0.20 \\
\hline Nickel sulphate & 0.05 \\
\hline Sodium tungstate & 0.13 \\
\hline Citric acid & 0.29 \\
\hline
\end{tabular}

After the Fe-Ni-W layer plating, a nickel layer was electroplated onto the existing $\mathrm{Fe}-\mathrm{Ni}-\mathrm{W}$ layer using Watt's electrolyte, containing nickel sulphate, nickel chloride and boric acid. ${ }^{21}$ The anode and cathode in this

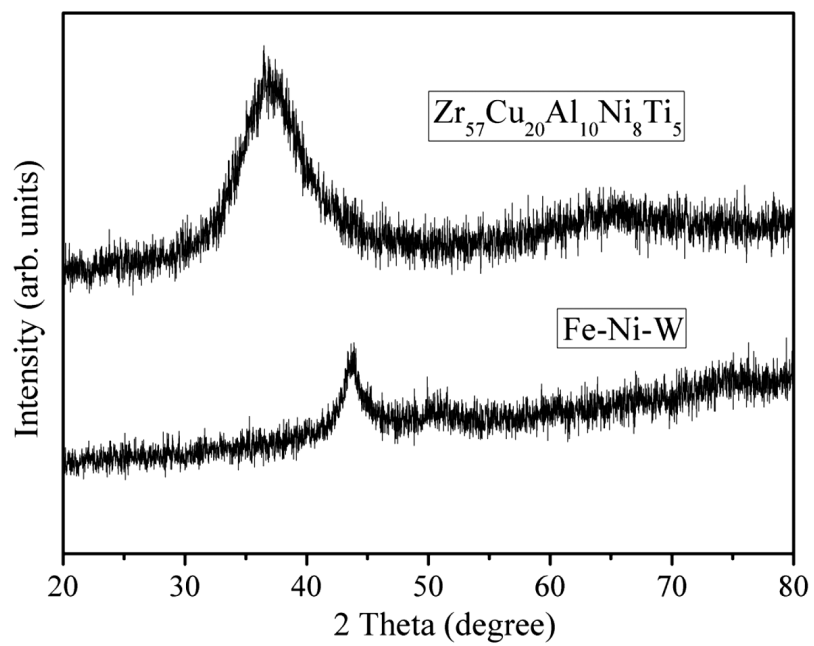

Figure 1: $\mathrm{XRD}$ patterns of the $\mathrm{Zr}_{57} \mathrm{Cu}_{20} \mathrm{Al}_{10} \mathrm{Ni}_{8} \mathrm{Ti}_{5} \mathrm{BMG}$ and the amorphous Fe-Ni-W coating

Slika 1: Rentgenogram BMG $\mathrm{Zr}_{57} \mathrm{Cu}_{20} \mathrm{Al}_{10} \mathrm{Ni}_{8} \mathrm{Ti}_{5}$ in amorfnega $\mathrm{Fe}-\mathrm{Ni}-\mathrm{W}$ nanosa step were a pure-nickel sheet and an MG-coated specimen, respectively, and the current was set at $30 \mathrm{~mA}$ for $3 \mathrm{~h}$. Both electroplating experiments were carried out at room temperature and the solution was constantly stirred with a magnetic rod to keep the electrolyte homogeneous during the entire electroplating process. The distance between the cathode and anode was kept constant, at about $30 \mathrm{~mm}$. Compressive tests of both uncoated and coated specimens were conducted at room temperature on a MTS 810 materials-testing system at a strain rate of $1 \cdot 10^{-4} \mathrm{~s}^{-1}$, using an extensometer (model 632.13F-20) to measure the strain. The Vickers-hardness data of the as-cast BMGs and the amorphous $\mathrm{Fe}-\mathrm{Ni}-\mathrm{W}$ coatings were obtained using a VH5N-B hardness tester.

\section{RESULTS AND DISCUSSION}

Figure 1 shows the XRD patterns of the as-cast BMG specimens and the electroplated Fe-Ni-W coatings. The results show two broad peaks, confirming the amorphous nature of the $\mathrm{Zr}_{57} \mathrm{Cu}_{20} \mathrm{Al}_{10} \mathrm{Ni}_{8} \mathrm{Ti}_{5}$ specimens and the Fe-Ni-W coating. The EDS results show that the composition of the amorphous $\mathrm{Fe}-\mathrm{Ni}-\mathrm{W}$ coating is $\mathrm{Fe}_{29.23} \mathrm{Ni}_{28.90} \mathrm{~W}_{41.87}$. A light image of the cross-section of a bilayer-confined BMG is shown in Figure 2. The thicknesses of the amorphous $\mathrm{Fe}-\mathrm{Ni}-\mathrm{W}$ layer and the $\mathrm{Ni}$ layer were found to be $75.28 \mu \mathrm{m}$ and $20.39 \mu \mathrm{m}$, respectively. It can be seen that the bilayer coating has a good appearance and the two layers are embedded together with no visible microcracks at the interface.

Figure 3 illustrates the compressive stress-strain curves for the uncoated and bilayer-coated BMGs. When compared with the uncoated BMG, although the bilayer-confined BMG has a smaller yield strength, its macroscopic plasticity is enhanced from $1.3 \%$ to $10.7 \%$. When comparing the results obtained in this experiment with those obtained by Chen et al. using a similar $\mathrm{Cu} / \mathrm{Ni}$ bilayer-confined $\mathrm{BMG}^{17}$ both specimens

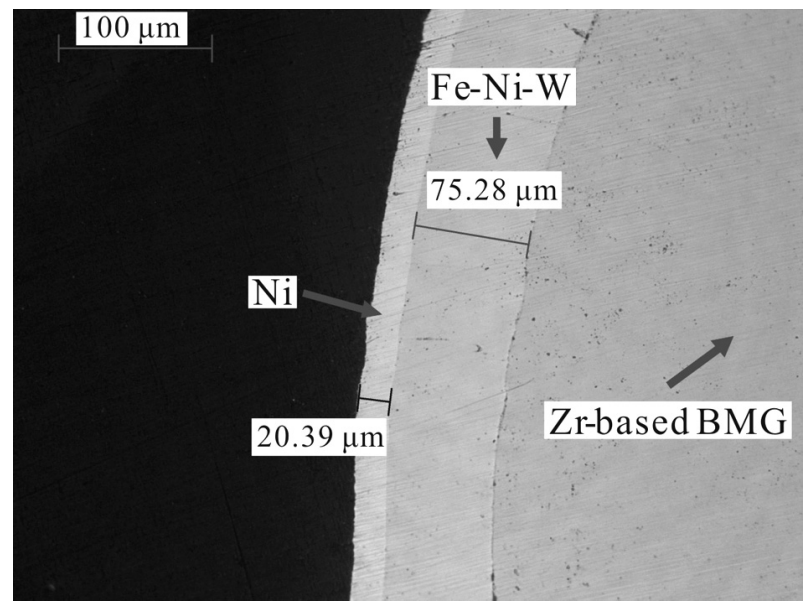

Figure 2: Light image of the amorphous $\mathrm{Fe}-\mathrm{Ni}-\mathrm{W} / \mathrm{Ni}$ bilayer-coated BMG

Slika 2: Svetlobni posnetek BMG, pokritega z amorfnim dvoplastnim $\mathrm{Fe}-\mathrm{Ni}-\mathrm{W} / \mathrm{Ni}$ nanosom 


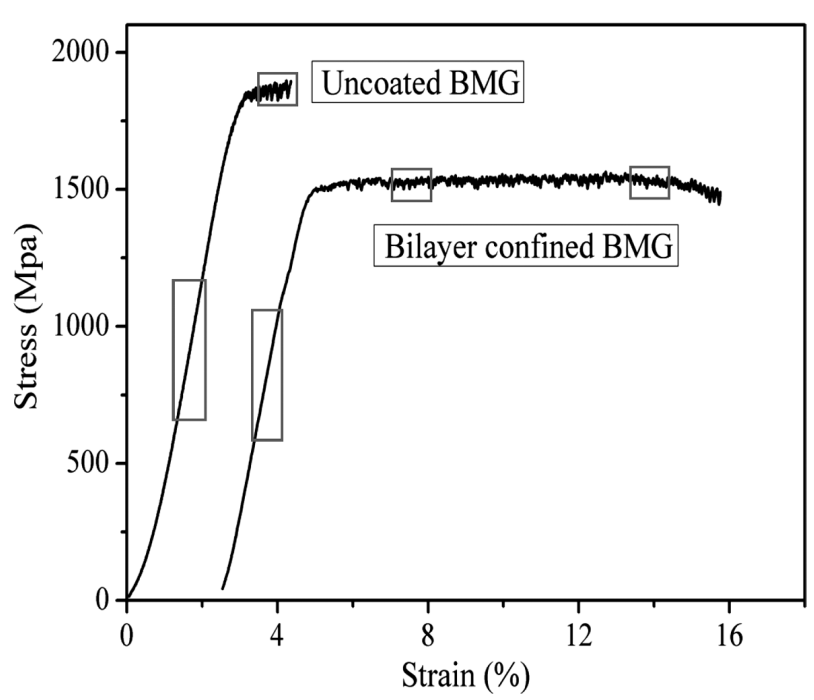

Figure 3: Compressive stress-strain curves for the uncoated and bilayer-coated BMG specimens

Slika 3: Krivulje napetost-raztezek pri tlačnem preizkusu BMG, brez nanosa in $\mathrm{z}$ dvoplastnim nanosom

show similar plasticity values, but the current plateaustress level for the amorphous Fe-Ni-W/Ni coated BMG is notably higher than for the $\mathrm{Cu} / \mathrm{Ni}$ coated $\mathrm{BMG}$. It is obvious that the amorphous $\mathrm{Fe}-\mathrm{Ni}$-W/Ni coated specimen has a much wider plastic-deformation range with a relatively stable plastic flow, and an insignificant decrement in the plastic-flow stresses when compared with the as-cast BMG and the BMGs coated with a single layer of $\mathrm{Ni}$ or $\mathrm{Cu}$, or coated with a $\mathrm{Cu} / \mathrm{Ni}$ bilayer. ${ }^{17}$
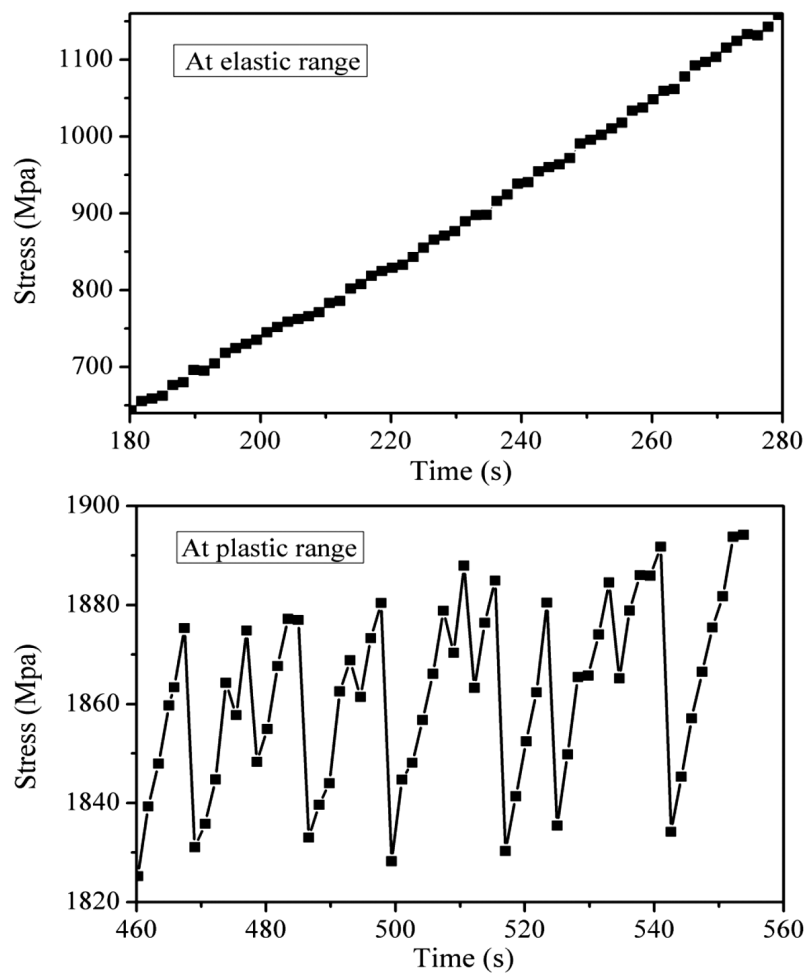

Figure 4: Flow serrations of the uncoated BMG

Slika 4: Nazobčan potek krivulje pri BMG brez nanosa
It is well known that a stress increase during the plastic flow of BMGs is correlated with the arrest of the propagating shear bands. However, when a shear band is initiated and starts to propagate, there is a corresponding displacement burst, which is linked to a stress decrease. ${ }^{22}$ Repeated stress increases and decreases result in serrations as the plastic flow proceeds. Such successive serrations are recognized as arising from an emission of new shear bands and a propagation of the existing ones. ${ }^{17}$ To obtain detailed information on the serrated flow between the uncoated BMG and the bilayer- confined BMGs, five ranges (as indicated by the rectangles in Figure 3) of the stress-strain curves were magnified and shown in Figures 4 and $\mathbf{5}$, respectively.

Since the bilayer-confined BMG specimen has a much larger plasticity, two plastic ranges were magnified in Figure 5. As shown in Figures $\mathbf{4}$ and 5, during the elastic ranges, the stress increases linearly with time, while during the plastic ranges, serrated flows are clearly
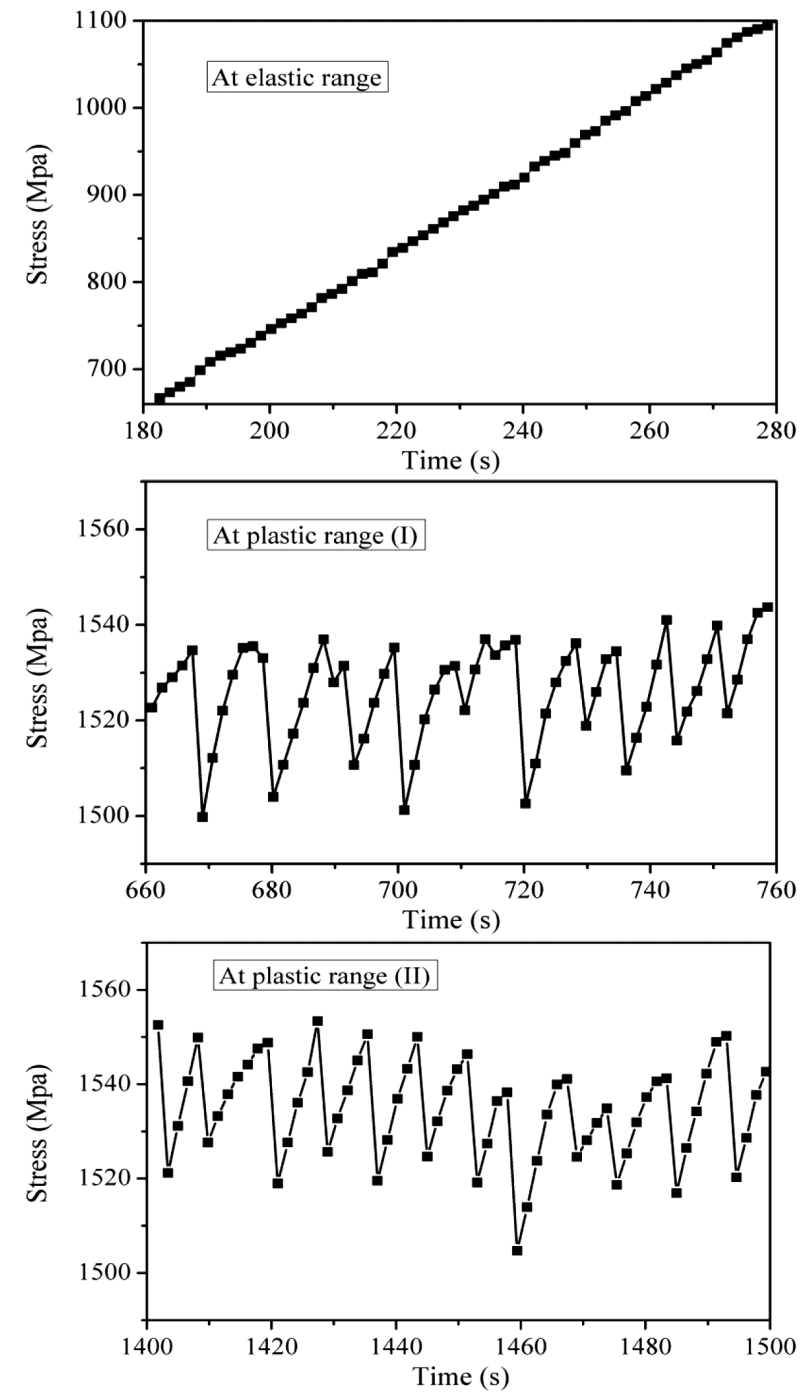

Figure 5: Flow serrations of the bilayer-coated BMG

Slika 5: Nazobčan potek krivulje pri BMG z dvoplastnim nanosom 


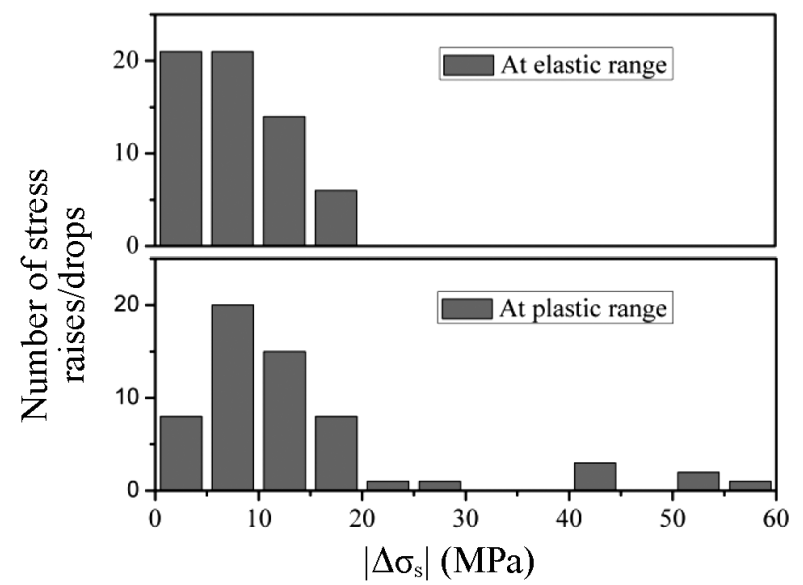

Figure 6: Statistical results of the number of stress loads/drops for the uncoated BMG

Slika 6: Statistični rezultati številnih obremenitev in razbremenitev pri BMG brez nanosa

observed for both kinds of BMG specimens. However, the amplitude of the serrated flow in the bilayer-confined BMGs is much smaller compared to that of the uncoated BMG. The serrated flow of the BMGs is found to be related to the shear-band propagation and termination, dissipating the plastic-deformation energy. ${ }^{23,24} \mathrm{~A}$ smaller amplitude indicates that the rapid avalanching of the load in a specimen was significantly confined. ${ }^{25}$

Flow serrations are the result of intermittent sample sliding and the formation of shear bands along the principal shear plane. ${ }^{8,17}$ To characterise the flow serrations, an absolute value of the stress raises/drops

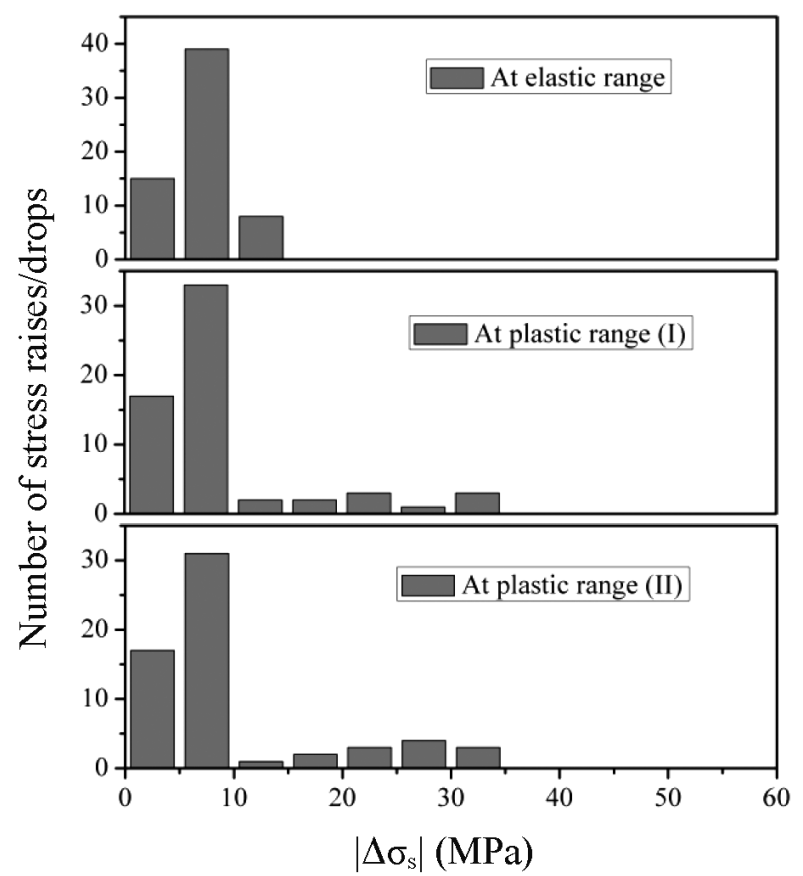

Figure 7: Statistical results of the number of stress loads/drops for the bilayer-confined BMG

Slika 7: Statistični rezultati številnih obremenitev/razbremenitev pri BMG z dvoplastnim nanosom
$\left(\left|\Delta \sigma_{s}\right|=\left|\sigma_{n+1}-\sigma_{n}\right|\right.$, where $\sigma_{n+1}$ and $\sigma_{n}$ are two neighbouring values of the stresses on the stress-strain curves) was introduced. Detailed statistical results of the $\left|\Delta \sigma_{s}\right|$ values of the selected ranges from Figures $\mathbf{4}$ and $\mathbf{5}$ are shown as histograms in Figures $\mathbf{6}$ and 7, respectively. It can be seen that, in the plastic ranges, the uncoated BMG shows a large stress drop of up to $60 \mathrm{MPa}$ (Figure 6), while the bilayer-confined BMG has a relatively smaller stress drop, no larger than $35 \mathrm{MPa}$ (Figure 7).

The smaller amplitudes of the stress drops indicate that the specimen has a smaller axial displacement during the avalanches ${ }^{8}$ and that it can more easily self-organize to a critical state to obtain enhanced macroscopic plasticity. ${ }^{25}$ Moreover, the number of the stress drops for the bilayer-confined BMGs is larger than for the uncoated BMG specimen (due to the vibration of the testing machine, only stresses larger than $12 \mathrm{MPa}$ were determined here), ${ }^{25}$ illustrating the initiation of more shear bands in the bilayer-confined BMGs.

A serrated flow can also be explained as a cycle of elastic-energy accumulation (stress raise) and release (stress drop): a larger serration magnitude corresponds to a higher elastic-energy density. As discussed earlier, the serrations obtained for the bilayer-confined BMG are of a small amplitude and a larger frequency, and their corresponding elastic energies are not dense enough for the shear bands to propagate through the cross-section of the specimen..$^{910}$ A large number of small serration flows is a good indicator that the bilayer-confined specimen can release the elastic energy in multiple small bursts rather than releasing all the stored energy in one shear band, thus extending the plastic deformation stage in a more stable manner without a large decrease in the stress.

Several studies have shown that the geometric confinement is able to significantly affect the plastic flow. ${ }^{14-17}$ The process of electroplating can cause a residual stress at the interface between the coating and the BMG. ${ }^{26}$ During the elastic loading, a mismatch in Poisson's ratio of the BMG and the coating leads to a confining stress on the BMG, and the maximum geometrical confining stress after reaching the yield strength can be estimated using formula $\sigma_{\max }=\sigma_{\mathrm{y}} \ln (b / a),{ }^{27}$ where $\sigma_{\max }, \sigma_{y}, a$ and $b$ denote the maximum confining stress, the yield strength of the bilayer coating, the inner diameter and the outer diameter of the specimen, respectively.

By replacing part of the $\mathrm{Ni}$ coating with an amorphous Fe-Ni-W coating, the large yield strength of a Fe-based BMG enables larger confining stresses on the BMG matrix..$^{28}$ Upon loading, the shear bands start propagating on the surface of the uncoated BMG and deformation occurs through the primary shear band, leading to a catastrophic failure. When the bilayer coating is in the place, it inhibits the rapid propagation of single shear bands, causing them to branch out instead. ${ }^{17}$ The enlargement of the confined stress arrests the propagation of the shear bands, preventing the catastrophic failure from the 
avalanches and resulting in a stable plastic flow before the failure. ${ }^{16,25}$

Recently, many studies have reported that the interface can induce the initiation of more smaller shear bands and the corresponding increased interactions (branching and arresting) between the shear bands that, in turn, increase the plasticity of a coated specimen. ${ }^{16,19}$ Besides the confining effect, the outside nickel layer is also found to be effective at hindering the propagation of the shear bands, dissipating the stored elastic energy in the core BMG. ${ }^{16}$ Moreover, since the hardness of the Fe-Ni-W coatings (measured as $647 \mathrm{HV}$ ) is much larger than the hardness of the BMG specimen (about $442 \mathrm{HV}$ ), the inner Zr-BMG layer may act as the softer phase, initiating the shear bands, and the outer amorphous Fe-Ni-W layer may act as the harder phase, inhibiting the propagation of the shear bands. ${ }^{29,30}$

The complicated mechanisms for the initiation and propagation of the shear bands (intermittent sliding) in the bilayer-confined BMGs may need further verification; however, the corresponding serrated flow shown in the stress-strain curves, without much decrease in the loads, distinctly illustrates the stable plastic flow in the bilayer-confined BMGs. This provides a feasible route for achieving a stable plastic flow in the BMGs for industrial applications and guidance in understanding the plastic-deformation mechanism in geometrically confined BMGs.

\section{CONCLUSIONS}

An amorphous Fe-Ni-W/Ni bilayer was successfully applied onto a Zr-based BMG through electroplating. The bilayer-confined BMG exhibits greatly enhanced macroscopic plasticity before failure, without much decrease in the loads during the serrated-flow stage. The statistical results of the flow serrations show that the bilayer-confined BMG has smaller amplitudes and larger frequencies of stress decreases. The enhanced stability of the plastic flow in the bilayer-confined BMGs may be mainly due to the large confining effect caused by the amorphous layer. The present work not only proposes a feasible route to achieve a more stable plastic flow in BMGs but also gives more insight into the plastic-deformation mechanisms of geometrically confined BMGs.

\section{Acknowledgements}

The work described in this paper was supported by a grant from the Research Grants Council of the Hong Kong Special Administrative Region, China (Project No. PolyU 511510).

\section{REFERENCES}

${ }^{1}$ A. R. Yavari, J. J. Lewandowski, J. Eckert, Mechanical properties of bulk metallic glasses, MRS Bulletin, 32 (2007) 8, 635-638, doi: $10.1557 / \mathrm{mrs} 2007.125$
${ }^{2}$ W. H. Wang, C. Dong, C. H. Shek, Bulk metallic glasses, Materials Science and Engineering R, 44 (2004) 2-3, 45-89, doi:10.1016/ j.mser.2004.03.001

${ }^{3}$ A. L. Greer, Metallic glasses ... on the threshold, Materials Today, 12 (2009) 1-2, 14-22, doi:10.1016/S1369-7021(09)70037-9

${ }^{4}$ S. H. Chen, K. C. Chan, F. F. Wu, L. Xia, Pronounced energy absorption capacity of cellular bulk metallic glasses, Applied Physics Letters, 104 (2014) 11, 111907, doi:10.1063/1.4869229

${ }^{5}$ S. H. Chen, K. C. Chan, L. Xia, Deformation behavior of a Zr-based bulk metallic glass under a complex stress state, Intermetallics, 43 (2013), 38-44, doi:10.1016/j.intermet.2013.07.006

${ }^{6}$ S. H. Chen, K. C. Chan, L. Xia, Deformation behavior of bulk metallic glass structural elements, Materials Science and Engineering A, 606 (2014), 196-204, doi:10.1016/j.msea.2014.03.094

${ }^{7}$ A. S. Argon, Plastic-Deformation in Metallic Glasses, Acta Metallurgica, 27 (1979) 1, 47-58, doi:10.1016/0001-6160(79)90055-5

${ }^{8}$ S. X. Song, H. Bei, J. Wadsworth, T. G. Nieh, Flow serration in a Zr-based bulk metallic glass in compression at low strain rates, Intermetallics, 16 (2008) 6, 813-818, doi:10.1016/j.intermet.2008.03.007

${ }^{9}$ C. N. Kuo, H. M. Chen, X. H. Du, J. C. Huang, Flow serrations and fracture morphologies of $\mathrm{Cu}$-based bulk metallic glasses in energy release perspective, Intermetallics, 18 (2010) 8, 1648-1652, doi:10.1016/j.intermet.2010.04.018

${ }^{10}$ J. W. Qiao, Y. Zhang, P. K. Liaw, Serrated flow kinetics in a Zr-based bulk metallic glass, Intermetallics, 18 (2010) 11, 2057-2064, doi:10.1016/j.intermet.2010.06.013

${ }^{11}$ S. X. Song, T. G. Nieh, Flow serration and shear-band viscosity during inhomogeneous deformation of a $\mathrm{Zr}$-based bulk metallic glass, Intermetallics, 17 (2009) 9, 762-767, doi:10.1016/j.intermet. 2009.03.005

${ }^{12}$ W. J. Wright, R. Saha, W. D. Nix, Deformation mechanisms of the $\mathrm{Zr}_{40} \mathrm{Ti}_{14} \mathrm{Ni}_{10} \mathrm{Cu}_{12} \mathrm{Be}_{24}$ bulk metallic glass, Materials Transactions, 42 (2001) 4, 642-649, doi:10.2320/matertrans.42.642

${ }^{13}$ B. A. Sun, S. Pauly, J. Tan, M. Stoica, W. H. Wang, U. Kuhn, J. Eckert, Serrated flow and stick-slip deformation dynamics in the presence of shear-band interactions for a Zr-based metallic glass, Acta Materialia, 60 (2012) 10, 4160-4171, doi:10.1016/j.actamat.2012. 04.013

${ }^{14}$ H. Q. Li, L. Li, C. Fan, H. Choo, P. K. Liaw, Nanocrystalline coating enhanced ductility in a Zr-based bulk metallic glass, Journal of Materials Research, 22 (2007) 2, 508-513, doi:10.1557/Jmr.2007. 0060

${ }^{15}$ W. Chen, K. C. Chan, P. Yu, G. Wang, Encapsulated Zr-based bulk metallic glass with large plasticity, Materials Science and Engineering A, 528 (2011) 6, 2988-2994, doi:10.1016/j.msea.2010.12.077

${ }^{16}$ W. Chen, K. C. Chan, S. F. Guo, P. Yu, Plasticity improvement of an Fe-based bulk metallic glass by geometric confinement, Materials Letters, 65 (2011) 8, 1172-1175, doi:10.1016/j.matlet.2011.01.030

${ }^{17}$ W. Chen, K. C. Chan, S. H. Chen, S. F. Guo, W. H. Li, G. Wang, Plasticity enhancement of a Zr-based bulk metallic glass by an electroplated $\mathrm{Cu} / \mathrm{Ni}$ bilayered coating, Materials Science and Engineering A, 552 (2012), 199-203, doi:10.1016/j.msea.2012.05.031

${ }^{18}$ T. G. Nieh, Y. Yang, J. Lu, C. T. Liu, Effect of surface modifications on shear banding and plasticity in metallic glasses: An overview, Progress in Natural Science: Materials International, 22 (2012) 5 , 355-363, doi:10.1016/j.pnsc.2012.09.006

${ }^{19}$ J. P. Chu, J. E. Greene, J. S. C. Jang, J. C. Huang, Y. L. Shen, P. K. Liaw, Y. Yokoyama, A. Inoue, T. G. Nieh, Bendable bulk metallic glass: Effects of a thin, adhesive, strong, and ductile coating, Acta Materialia, 60 (2012) 6-7, 3226-3238, doi:10.1016/j.actamat.2012. 02.037

${ }^{20}$ F. J. He, J. Yang, T. X. Lei, C. Y. Gu, Structure and properties of electrodeposited Fe-Ni-W alloys with different levels of tungsten content: A comparative study, Applied Surface Science, 253 (2007) 18, 7591-7598, doi:10.1016/j.apsusc.2007.03.068 
${ }^{21}$ L. Mirkova, G. Maurin, M. Monev, C. Tsvetkova, Hydrogen coevolution and permeation in nickel electroplating, Journal of Applied Electrochemistry, 33 (2003) 1, 93-100, doi:10.1023/ A: 1022957600970

${ }^{22}$ H. M. Chen, C. J. Lee, J. C. Huang, T. H. Li, J. S. C. Jang, Flow serration and shear-band propagation in porous Mo particles reinforced Mg-based bulk metallic glass composites, Intermetallics, 18 (2010) 6, 1240-1243, doi:10.1016/j.intermet.2010.03.024

${ }^{23}$ A. Lemaitre, C. Caroli, Rate-Dependent Avalanche Size in Athermally Sheared Amorphous Solids, Physical Review Letters, 103 (2009) 6, 065501, doi:10.1103/Physrevlett.103.065501

${ }^{24}$ D. Klaumunzer, R. Maass, F. H. Dalla Torre, J. F. Loffler, Temperature-dependent shear band dynamics in a Zr-based bulk metallic glass, Applied Physics Letters, 96 (2010) 6, 061901, doi:10.1063/ 1.3309686

${ }^{25}$ G. Wang, K. C. Chan, L. Xia, P. Yu, J. Shen, W. H. Wang, Self-organized intermittent plastic flow in bulk metallic glasses, Acta Materialia, 57 (2009) 20, 6146-6155, doi:10.1016/j.actamat.2009. 08.040
${ }^{26}$ S. J. Hearne, J. A. Floro, Mechanisms inducing compressive stress during electrodeposition of Ni, Journal of Applied Physics, 97 (2005) 1, 014901, doi:10.1063/1.1819972

${ }^{27}$ G. Ravichandran, J. Lu, Pressure-dependent flow behavior of $\mathrm{Zr}_{41.2} \mathrm{Ti}_{13.8} \mathrm{Cu}_{12.5} \mathrm{Ni}_{10} \mathrm{Be}_{22.5}$ bulk metallic glass, Journal of Materials Research, 18 (2003) 9, 2039-2049, doi:10.1557/Jmr.2003.0287

${ }^{28}$ X. J. Gu, S. J. Poon, G. J. Shiflet, Mechanical properties of ironbased bulk metallic glasses, Journal of Materials Research, 22 (2007) 2, 344-351, doi:10.1557/Jmr.2007.0036

${ }^{29}$ X. H. Du, J. C. Huang, K. C. Hsieh, Y. H. Lai, H. M. Chen, J. S. C. Jang, P. K. Liaw, Two-glassy-phase bulk metallic glass with remarkable plasticity, Applied Physics Letters, 91 (2007) 13, 131901, doi:10.1063/1.2790380

${ }^{30}$ S. H. Chen, K. C. Chan, L. Xia, Effect of stress gradient on the deformation behavior of a bulk metallic glass under uniaxial tension, Materials Science and Engineering A, 574 (2013), 262-265, doi:10.1016/j.msea.2013.03.035 